ENTREPRENEURSHIP AND SUSTAINABILITY ISSUES

ISSN 2345-0282 (online) http://jssidoi.org/jesi/

2019 Volume 6 Number 4 (June)

http://doi.org/10.9770/jesi.2019.6.4(43)

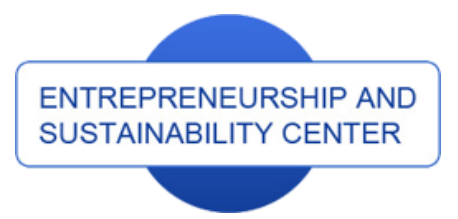

Publisher

http://jssidoi.org/esc/home

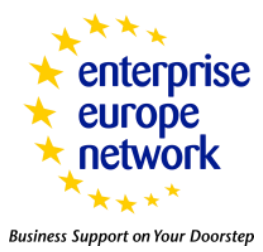

CASPA

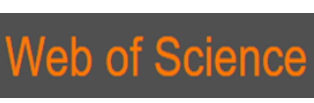

1. Clarivate

Analytics

\title{
MODELING OF RESULTANT EFFECTS IN ASSESSMENT OF INNOVATIVE ACTIVITY OF THE HOTEL ORGANIZATIONS
}

\author{
Sayabek Ziyadin ${ }^{1}$, Nataliya Shash ${ }^{2}$, Tatyana Levchenko ${ }^{3}$, Saltanat Khudaibergenova ${ }^{4}$, Gulmira Yessenova $^{5}$ \\ ${ }^{1,4}$ Al-Farabi Kazakh National University, 71, al-Farabi ave., Almaty, Kazakhstan \\ ${ }^{2}$ Plekhanov Russian University of Economics, 36, Stremyanny lane, Moscow, Russian Federation \\ ${ }^{3}$ Sochi State University, 94, Plastunskaya str., Sochi, Russian Federation \\ ${ }^{5}$ Seifullin Kazakh AgroTechnical University, 62, Zhenis str., Nursultan, Kazakhstan \\ E-mails: ${ }^{1}$ sayabekz@gmail.com, ${ }^{2}$ shash.nn@rea.ru, ${ }^{3}$ lekonst@mail.ru, ${ }^{4}$ saltanat_jsf@mail.r, ${ }^{5}$ pavlodarsemey@mail.ru
}

Received 20 March 2019; accepted 10 June 2019; published 30 June 2019

\begin{abstract}
Now much attention is paid to development of innovative and digital technologies, advance on the market of innovations of grocery, technological and also organizational and administrative character that result, as a rule, are resultant effects. The tourism industry - an important element of any economic system where resultant effects are shown especially brightly and visually, owing to continuous emergence of new requirements. The innovative activity of the hotel organizations in this context is of particular importance consisting in need of obtaining by them competitive advantages and fuller satisfaction of dynamically changing consumer demand for the tourist product made by them. To assess the innovative activity of organizations and its innovative competitiveness are widely used indicators of innovative activity of the organization. One of the main directions for the creation of quality services is the strict observance of the parameters of comfort, which are developed by the practice of the tourist business and are universal for hotels, catering facilities or a travel company. The most significant innovative technologies include the use of the Internet in order to promote and implement a tourist product and real competition for tourism organizations.
\end{abstract}

Keywords: resultant effect; innovative activity; hotel business; factorial model; stochastic count; indicators; assessment of innovative activity; hotel organizations

Reference to this paper should be made as follows: Ziyadin, S.; Shash, N.; Levchenko, T., Khudaibergenova, S.; Yessenova' G. 2019. Modeling of resultant effects in assessment of innovative activity of the hotel organizations, Entrepreneurship and Sustainability Issues 6(4): 2180-2193. http://doi.org/10.9770/jesi.2019.6.4(43)

JEL Classifications: L83, O32, O35, C15, C38 


\section{ENTREPRENEURSHIP AND SUSTAINABILITY ISSUES}

ISSN 2345-0282 (online) http://jssidoi.org/jesi/

2019 Volume 6 Number 4 (June)

http://doi.org/10.9770/jesi.2019.6.4(43)

\section{Introduction}

Innovation activity in the hotel business causes not only the creation of qualitatively new business systems and the connections between their structural elements, but also the formation of a group of resulting effects.

The issues of evaluating the innovative activity of hotel organizations from the point of view of identifying the final results with appropriate efficiency are becoming ever more relevant (e.g. Panfiluk, Szymańska, 2017; Shevyakova et al. 2019; Chkalova et al. 2019). The objectives of this assessment, in our opinion, it is advisable to present in two plans (Anisimov Yu. P. et al. 2006; Vertakova, Yu.V. et al, 2012):

1) private assessment of the readiness of the hotel organization to implement a single innovation process;

2) an integral assessment of the current state of the hotel organization with respect to all or a group of innovative processes already being implemented.

The innovative potential is commonly understood as the measure of readiness to accomplish the tasks that ensure the achievement of the goals of innovation activity. Innovation sustainability is interpreted by us as the ability of an organization to preserve a predetermined level of achievement of a set of goals of innovation activity (quality and novelty of products or services sold, scientific and technical level of the material and technical structure, stability of resource provision, state of innovation potential, nature of innovation management) under the influence factors of a dynamically transforming market business environment. The intensity of innovation in this context characterizes the amount of expenditure of the enterprise, directed to the introduction of innovations to improve the production technology of the product or the provision of services.

\section{Litreture review}

The study of the theory and practice of digitization of hotel organizations, digitalization in tourism is based in the numerous works, where the dynamics of development of technologies in the field of tourism is being examined. E.g. researchers Akaka, \& Vargo (2014) wrote that they explored the role and scope of technology in value cocreation, service innovations and service systems - configurations of co-creation of technology value and people's offerings, tourist flows and the development of this sector were reviewed by Pröbstl-Haider (2014), Tarlow (2007), Medlik (2012). A study of the theory and practice of economic tourism processes based in Van der Wagen, \& White (2018), Ryan (2012), Wells, \& Smith (2014), Getz, \& Page (2008) Backman (2018). Issues of socio-economic efficiency of diversification in tourism are highlighted in Battour, \& Ismail (2016), Mohsin et al. (2016), Pertrenko et al. (2019). Issues of socio-economic efficiency digitalization, innovation processes in the field of tourism are highlighted in the works of Buhalis, \& Low (2008), Munar (2012), Nikolova, Hassan (2013), Ziyadin, \& Kabasheva (2018). They investigated the digitalization processes in the tourism industry. Researchers Ziyadin et al. (2019) reviewed the processes of diversification and digitalization in the field of tourism. Tarlow (2007) wrote in his work that tourism security is an important part of both security management and tourism. Pröbstl-Haider et al. (2014) described in his research the tourism industry that it offers a dedicated outlet for research relevant to social sciences and natural resources, all aspects of outdoor recreation planning and management, covering the entire spectrum of settings from wilderness. Medlik (2012) mentioned that managing tourism presents research studies that analyze the trends and information on the wide spectrum of tourism activities and industries.

\section{Methodology}

The development of innovative activity of the hotel organization as an integrated system can only be carried out through the development of its components (Bovin 2011). We have proposed a methodical approach to assessing the innovative activity of hotel organizations based on the modeling of the resulting effects in direct relation to specific innovation processes. 
The resulting effects can be determined by the state of the aggregate of innovation processes: $\mathrm{P}=\left(\mathrm{P}_{1}, \mathrm{P}_{2}, \ldots, \mathrm{P}_{\mathrm{n}}\right)$. The state of each process depends on the state of the elements of innovation activity (EIA), in particular, innovation potential (IP), innovation sustainability (IS), intensity of innovation activity (AI), based on certain innovation processes (Beketov, 2008; Dezhkina 2012).

Innovative activity of hotel organizations can be schematically represented as follows (Figure 1).

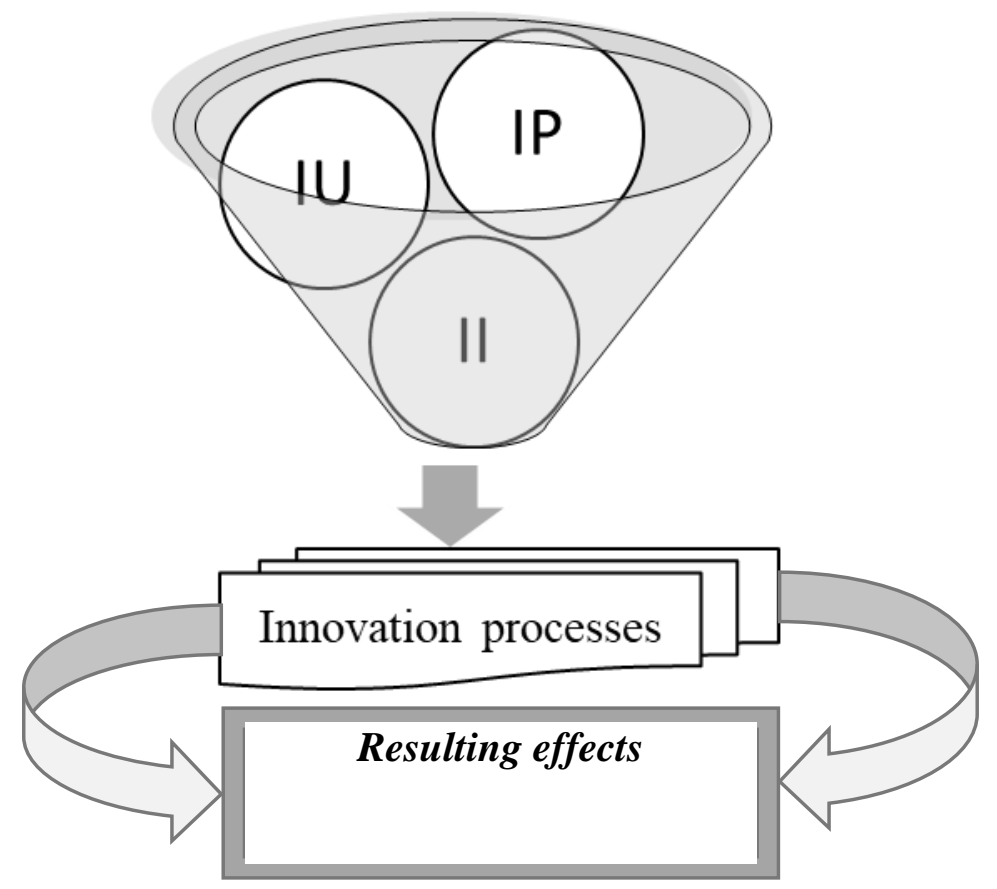

Figure 1. Innovative activity of hotel organizations, creating the resulting effects

In evaluating innovation activity, the importance of the components is necessarily taken into account. The general scheme for assessing innovation activity is presented in Figure 2, where:

EIA (P) - compliance of elements of innovative activity with the implemented innovation processes;

$\mathrm{P}$ (EIA) - compliance of implemented innovation processes with elements of innovative activity;

PI (P) - compliance of the innovation potential of the totality of the implemented innovation processes;

PS (P) - compliance with the innovation sustainability of the totality of the implemented innovation processes;

AI (P) - compliance intensity of innovative activities of the totality of the implemented innovation processes.

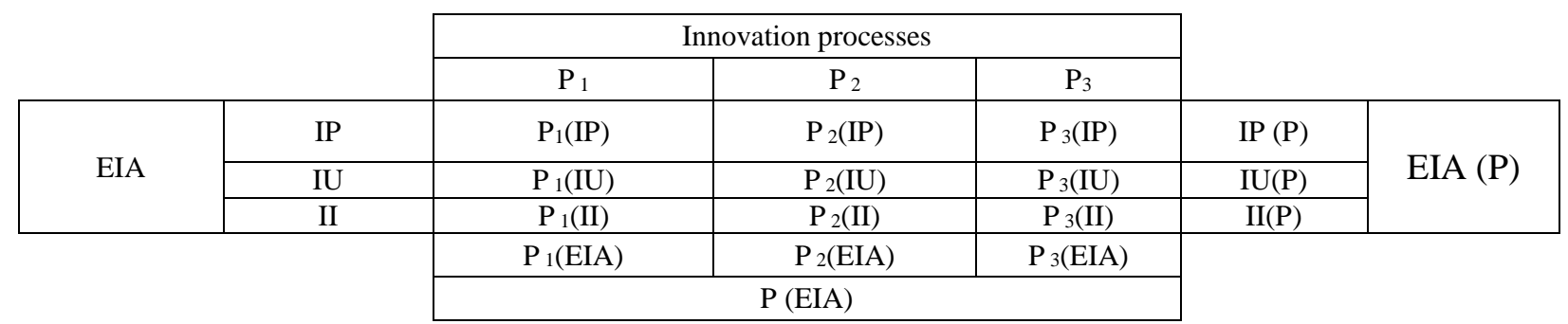

Figure 2. Matrix "innovation processes - elements of innovation activity" of hotel organizations 
Theoretical framework. All indicators characterizing the innovative activity of organizations are interrelated and interdependent. The connection between some of them is direct, and between others - indirect (Fathutdinov 2013).

To build a map of the interrelationships of the elements of innovation activity of hotel organizations, the main groups of indicators illustrating the characteristics of ongoing innovation processes were identified and used ( $\mathrm{N}$. Mariev, Savin 2010). The main indicators of the elements of innovation activity of hotel organizations and the formulas for their calculation are presented in Table 1.

Table 1. Indicators of elements of innovative activity of hotel organizations

\begin{tabular}{|c|c|c|}
\hline EIA indicators & Calculation formula & Legend \\
\hline \multicolumn{3}{|c|}{ Innovation potential } \\
\hline $\begin{array}{l}\text { Coefficient of innovation } \\
\text { ICP staff }\end{array}$ & $I C p=\frac{\mathrm{IPQ}}{\mathrm{APQ}}$ & $\begin{array}{c}\text { IPQ - the total number of staff } \\
\text { involved in innovation } \\
\text { the activities of the enterprise, pers .; } \\
\text { APQ - average number } \\
\text { enterprise staff, pers. }\end{array}$ \\
\hline $\begin{array}{l}\text { Share of employees } \\
\text { having a higher } \\
\text { education in general } \\
\text { HEPS staff }\end{array}$ & $\mathrm{HEPS}=\frac{\mathrm{HEQ}}{\mathrm{APQ}}$ & $\begin{array}{l}\text { HEQ- the number of employees with } \\
\text { higher education, pers .; } \\
\text { APQ - average number } \\
\text { enterprise staff, pers. }\end{array}$ \\
\hline $\begin{array}{l}\text { Share of employees } \\
\text { having a degree } \\
\text { in total } \\
\text { DPS staff } \\
\end{array}$ & $\mathrm{DPS}=\frac{\mathrm{DPQ}}{\mathrm{APQ}}$ & $\begin{array}{l}\text { DPQ - the number of employees with } \\
\text { academic degree, pers .; } \\
\text { APQ - average number } \\
\text { enterprise staff, pers. }\end{array}$ \\
\hline $\begin{array}{l}\text { Learning ratio } \\
\text { TPC staff }\end{array}$ & $\mathrm{TPC}=\frac{\mathrm{TPQ}}{\mathrm{APQ}}$ & $\begin{array}{c}\text { TPQ - the number of employees who passed } \\
\text { training and retraining, pers .; } \\
\text { APQ - average number } \\
\text { enterprise staff, pers. }\end{array}$ \\
\hline $\begin{array}{l}\text { Intellectual factor } \\
\text { IPRC property }\end{array}$ & $\mathrm{IPRC}=\frac{\mathrm{INA}}{\mathrm{NCA}}$ & $\begin{array}{l}\text { INA - intangible assets, rub :; } \\
\text { NCA - non-current assets, rub. }\end{array}$ \\
\hline TPIC Hotel Services Innovation Ratio & $\mathrm{TPIC}=\frac{\mathrm{VIIA}}{\mathrm{EV}}$ & $\begin{array}{l}\text { VIIA - volume of investments in innovative activity, } \\
\text { rubles; } \\
\text { EV - the total cost of the enterprise, }\end{array}$ \\
\hline CREC equity ratio & $\mathrm{CREC}=\frac{\mathrm{EC}}{\mathrm{IS}}$ & $\begin{array}{c}\text { EC - net worth, rub :; } \\
\text { IS - total sources of funds } \\
\text { (long-term and short-term), rub. }\end{array}$ \\
\hline $\begin{array}{l}\text { Coefficient } \\
\text { turnover of funds } \\
\text { in TRFA assets }\end{array}$ & $\mathrm{TRFA}=\frac{\mathrm{SR}}{\mathrm{ACA}}$ & $\begin{array}{l}\text { SR - revenue from the sale of hotel services, rub .; } \\
\text { ACA- average asset value, rub. }\end{array}$ \\
\hline \multicolumn{3}{|c|}{ Innovative sustainability } \\
\hline AUR autonomy ratio & $\mathrm{AUR}=\frac{\mathrm{EC}}{\mathrm{TB}}$ & $\begin{array}{l}\text { EC - equity capital, providing innovation, rub .; } \\
\text { TB - balance currency, rub. }\end{array}$ \\
\hline $\begin{array}{l}\text { The maneuverability of innovation } \\
\text { MANR }\end{array}$ & $\mathrm{MANR}=\frac{\mathrm{OCA}}{\mathrm{EC}}$ & $\begin{array}{c}\text { OCA - own circulating assets, providing innovative } \\
\text { activity of the company; } \\
\text { EC - net worth, rub .; }\end{array}$ \\
\hline Profitability of hotel services HSP & $\mathrm{HSP}=\frac{\text { Res }}{\text { HSTC }}$ & $\begin{array}{c}\text { Res - profit (loss) from } \\
\text { sales of hotel services, rub .; } \\
\text { HSTC - full cost price } \\
\text { hotel services, rub. }\end{array}$ \\
\hline PSR frame stability ratio & $\mathrm{PSR}=\frac{\mathrm{DP}}{\mathrm{APQ}}$ & $\begin{array}{c}\text { DP number of employees } \\
\text { with work experience at the enterprise for } 5 \text { and more } \\
\text { years, people; } \\
\text { APQ - average number }\end{array}$ \\
\hline
\end{tabular}




\begin{tabular}{|c|c|c|}
\hline & & enterprise staff, pers. \\
\hline IGR innovation growth rate & $\mathrm{IGR}=\frac{\mathrm{CIPr}}{\mathrm{OEC}}$ & $\begin{array}{l}\text { CIPr - cost of innovation processes, rub.; } \\
\text { OEC - the total cost of other investment expenses, rub. }\end{array}$ \\
\hline \multicolumn{3}{|c|}{ Intensity of innovation activity } \\
\hline $\begin{array}{l}\text { The share of innovation financing in the } \\
\text { revenue from the sale of hotel services } \\
\text { IFS }\end{array}$ & $\mathrm{IFS}=\frac{\mathrm{IFV}}{\mathrm{HIS}}$ & $\begin{array}{l}\text { IFV - the volume of financing innovation, rub .; } \\
\text { HIS - proceeds from the sale of hotel, RUB. }\end{array}$ \\
\hline $\begin{array}{l}\text { Share of financing of introduced } \\
\text { innovations in the total amount of FII } \\
\text { financed innovations }\end{array}$ & $\mathrm{FII}=\frac{\mathrm{FIV}}{\mathrm{TFI}}$ & $\begin{array}{c}\text { FIV - the volume of financing of introduced } \\
\text { innovations in the current year, rubles; } \\
\text { TFI - the total amount of financed innovations in the } \\
\text { current year, rub. }\end{array}$ \\
\hline $\begin{array}{c}\text { Coefficient } \\
\text { changes in the sales volume of hotel } \\
\text { services as a result of spending on } \\
\text { CHSS innovation }\end{array}$ & $\mathrm{CHSS}=\frac{\mathrm{SVe}}{\mathrm{SVS}}$ & $\begin{array}{c}\text { SVe - sales volume of hotel rooms. } \\
\text { end services } \\
\text { reporting period, rub .; } \\
\text { SVs - sales volume of hotel rooms } \\
\text { services at the beginning of the reporting period, rub. }\end{array}$ \\
\hline
\end{tabular}

The resulting effect of innovation processes is a multidimensional definition (P.N. Zavlina, et al., 2004). The magnitude of this effect, from our point of view, is directly determined by the expected efficiency, manifested from the position of the following approaches:

- production and technology;

- innovation and economic;

- socially oriented (Malysheva, \& Shestakov 2012).

The content of the resulting effects of the implementation of innovation processes from the standpoint of these approaches is proposed in Table 2 (Abdukarimov 2013; Galkina 2011; Rumyantseva, Egorova 2015).

Table 2. Content of the resulting effects of the implementation of innovative processes in hotel organizations

\begin{tabular}{|l|}
\hline \multicolumn{1}{|c|}{ Indicators of the production and technological result of the implementation of innovative processes (REPT) } \\
\hline The proportion of new IT \\
\hline Production automation ratio \\
\hline The proportion of innovative technological processes \\
\hline Tourist flow \\
\hline Revenue per 1 room-night \\
\hline Average annual load factor \\
\hline Duration of stay for 1 room \\
\hline Profit per 1 number \\
\hline Profitability of hotel services \\
\hline Revenue per number \\
\hline The average income per guest \\
\hline Indicators of the innovative economic result of the implementation of innovative processes (REI) \\
\hline Capital investment on the implementation of innovative processes \\
\hline Net present value of innovation processes \\
\hline Return on innovation processes \\
\hline Index of profitability of innovation processes \\
\hline Indicators of socially-oriented net effect of the implementation of innovative processes (RESH) \\
\hline Increase in revenue of the organization \\
\hline Profit per employee \\
\hline Profitability of labor resources \\
\hline Environmental and workplace safety \\
\hline
\end{tabular}

Source: Compiled by the authors 


\section{Results analysis}

To study the interaction of elements of innovative activity of hotel organizations with the resulting effects from the implementation of innovative processes, the technology of stochastic factor analysis was chosen.

The use of factor analysis, in particular, methods for studying the dimension of selected groups of factors and the matrix structure of their covariance and correlation, allows you to study comprehensively and measure how the value of the resulting indicators for the implementation of innovative processes depends on the impact factors and to determine linear statistical correlations of correlation and to identify the factors causing their presence (Sheremet 2011).

The choice of a stochastic (correlation) factor analysis based on a graphical and set-theoretic description by structuring innovative activity factors and indicators of the net effect of implementing innovation processes as a methodological approach is due to the multidimensionality and variability of these factors and indicators, as well as their interconnectedness and interdependence. However, the nature of their relationship is incomplete and probabilistic, and for a number of indicators there is a lack of full amount of quantitative information, which makes it necessary to use qualitative analysis to establish qualitative (causal) relationships between them (Abdukarimov, Narizhnyj 2014). The structuring process ends with the construction of a stochastic factor model.

The analysis procedure involves combining the most correlated among themselves factors of innovation activity with indicators of resulting effects. At the same time, the level of correlation of one factor with different indicators of the resulting effect can vary considerably. As a result of this procedure, latent variables are determined (Sheremet).

For the mathematical description of the factor model, we construct the correlation matrix corresponding to it and conduct some stages of factor analysis and stochastic modeling.

At the first stage, we proposed to build a stochastic matrix of innovation activity indicators (Table 3).

Table 3. Stochastic matrix of EIA indicators

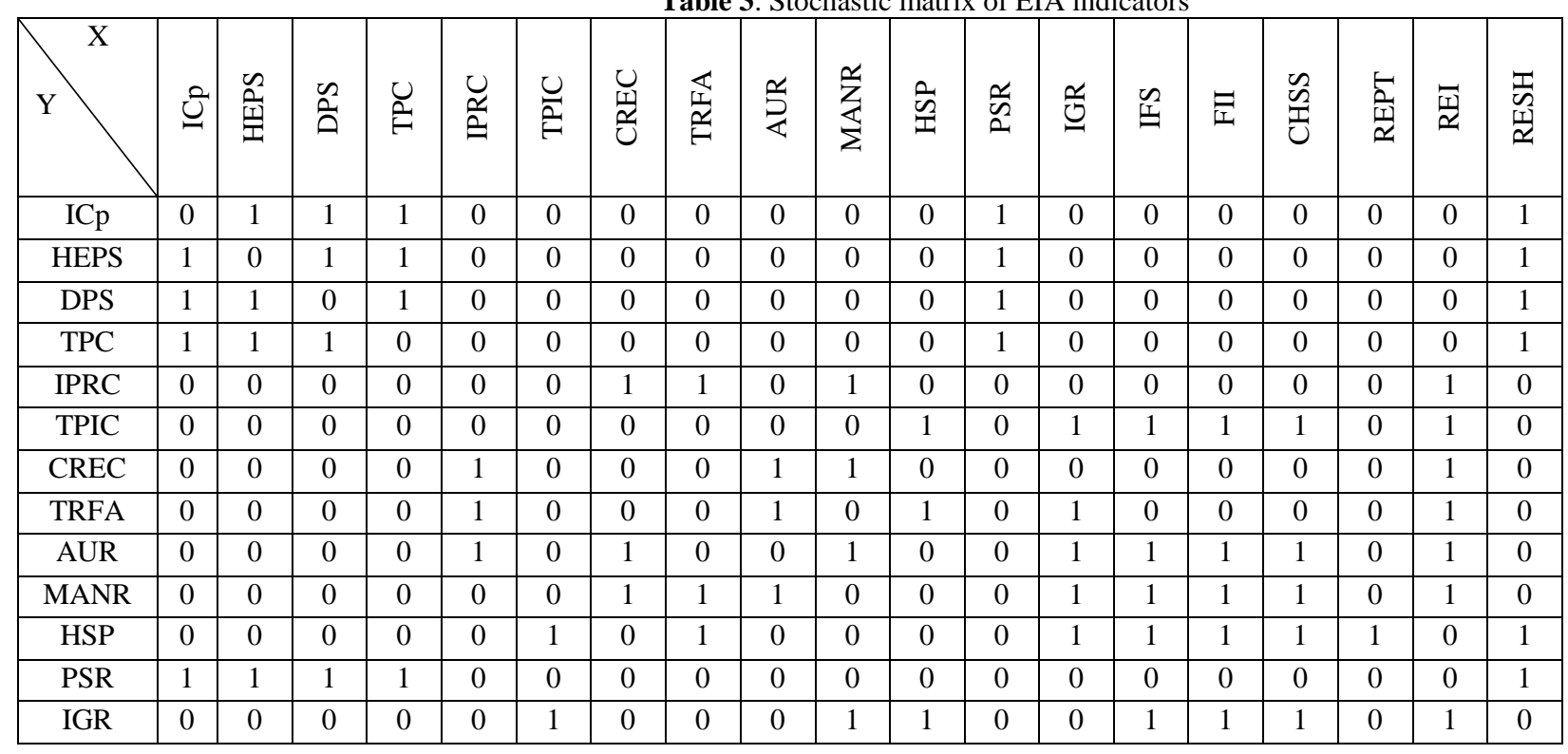


ENTREPRENEURSHIP AND SUSTAINABILITY ISSUES

ISSN 2345-0282 (online) http://jssidoi.org/jesi/

2019 Volume 6 Number 4 (June)

http://doi.org/10.9770/jesi.2019.6.4(43)

\begin{tabular}{|c|c|c|c|c|c|c|c|c|c|c|c|c|c|c|c|c|c|c|c|}
\hline IFS & 0 & 0 & 0 & 0 & 0 & 1 & 0 & 1 & 1 & 1 & 1 & 0 & 1 & 0 & 1 & 1 & 1 & 1 & 0 \\
\hline FII & 0 & 0 & 0 & 0 & 0 & 1 & 0 & 1 & 1 & 1 & 1 & 0 & 1 & 1 & 0 & 1 & 1 & 1 & 0 \\
\hline CHSS & 0 & 0 & 0 & 0 & 0 & 1 & 0 & 1 & 0 & 0 & 1 & 0 & 0 & 1 & 1 & 0 & 1 & 0 & 0 \\
\hline REPT & 0 & 0 & 0 & 0 & 0 & 0 & 0 & 1 & 0 & 0 & 1 & 0 & 0 & 1 & 0 & 1 & 0 & 1 & 0 \\
\hline REI & 0 & 0 & 0 & 0 & 1 & 1 & 1 & 1 & 1 & 1 & 1 & 0 & 1 & 1 & 1 & 0 & 1 & 0 & 0 \\
\hline RESH & 1 & 1 & 1 & 1 & 0 & 0 & 0 & 0 & 0 & 0 & 1 & 1 & 0 & 0 & 0 & 0 & 0 & 0 & 0 \\
\hline
\end{tabular}

At the next stage, it is proposed to calculate the number of units in each row and column, taking into account the calculation of the dimensions and the ordering of the indicators in descending order (Table 4).

Table 4. Ranking of stochastic relations of indicators of EIA of hotel organizations

\begin{tabular}{|c|c|c|c|c|c|c|c|c|c|c|c|c|c|c|c|c|c|c|c|}
\hline \multirow[t]{2}{*}{$\mathrm{X}$} & 10 & 9 & 9 & 7 & 7 & 7 & 6 & 5 & 5 & 5 & 4 & 4 & 4 & 4 & 4 & 4 & 4 & 3 & 3 \\
\hline & $\sqrt{\underline{1}}$ & $\begin{array}{l}\hat{\triangleq} \\
\text { I }\end{array}$ & 红 & 还 & 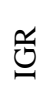 & $\overrightarrow{\mid \vec{I}}$ & $\begin{array}{l}n \\
\tilde{1} \\
\tilde{U}\end{array}$ & $\frac{2}{z}$ & $\frac{U}{R}$ & $\frac{2}{3}$ & 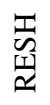 & 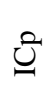 & $\begin{array}{l}\frac{n}{1} \\
\frac{1}{1}\end{array}$ & $\begin{array}{l}\tilde{2} \\
\tilde{0}\end{array}$ & ڤ్ & $\frac{\alpha}{\tilde{n}}$ & $\frac{5}{\underline{T}}$ & 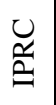 & 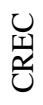 \\
\hline \multirow[t]{2}{*}{$\mathrm{Y}$} & 9 & 8 & 8 & 7 & 7 & 7 & 7 & 6 & 5 & 5 & 5 & 4 & 4 & 4 & 4 & 4 & 4 & 3 & 3 \\
\hline & $\sqrt{\underline{1}}$ & 珐 & 囯 & 占 & $\underset{\Sigma}{\stackrel{c}{z}}$ & $\begin{array}{l}\tilde{\tilde{\Omega}} \\
\underline{I}\end{array}$ & 过 & $\frac{U}{2}$ & $\begin{array}{l}n \\
\tilde{1} \\
\text { U }\end{array}$ & $\begin{array}{l}\mathbb{T} \\
\text { 瓷 }\end{array}$ & తి & $\begin{array}{l}\frac{2}{2} \\
\frac{1}{I}\end{array}$ & 合 & U. & 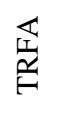 & $\begin{array}{l}\tilde{\omega} \\
\hat{2}\end{array}$ & $\underset{\frac{5}{x}}{\underline{x}}$ & 崩 & \begin{tabular}{l} 
UT \\
\multirow{2}{*}{}
\end{tabular} \\
\hline
\end{tabular}

A graphical depiction of the established relationships of the selected indicators and the resulting effects is shown in Figure 3.

The analysis shows the multidimensionality of the concept of "innovative activity of hotel organizations", and also allows us to characterize the relationship of its components.

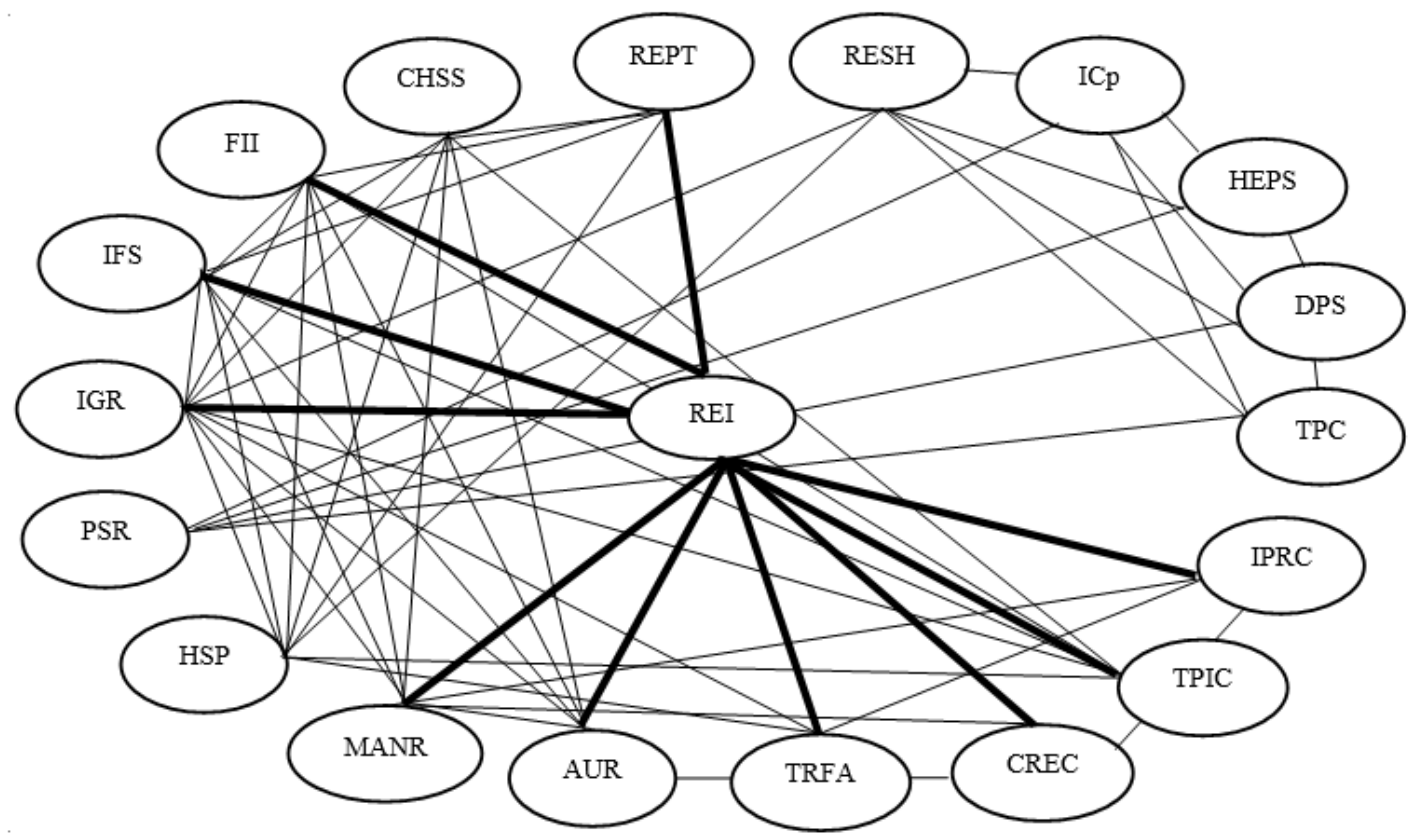

Figure 3. A stochastic graph of indicators of EIA and the resulting effects of innovative processes 
The prevailing number of links between indicators of the innovation and economic resulting effect of the innovation processes implemented by hotel organizations (REI) allows us to conclude about the most meaningful character of this component, which forms the center of the correlation graph and is a latent variable. This fact leads to the possibility and the need to allocate REI as a higher order variable.

Indicators of the share of financing innovation in the revenue from the sale of hotel services (IFS) and the share of financing of introduced innovations in the total amount of financed innovations (FII) are similar in the number of linear connections and have a high correlation coefficient.

Among the elements of innovation activity, indicators of the intensity of innovation activity have the largest share of correlation. The lowest level of correlation is demonstrated by indicators reflecting the qualitative composition of the organization's personnel.

At the final stage, we will conduct a quantitative assessment of the innovative activity of hotel organizations. The values for all indicator blocks for the ten selected hotel organizations in Sochi are presented in Table 5. The selection of these organizations is based on close categorical affiliation (3-4 stars), a comparable number of rooms and proximity in the location, which allows considering them as competing, and also justifies the possibility of comparing them (Kokurin 2011; Kuznetsova, Rud'2013). The names of the organizations were not disclosed in order to preserve confidential information.

Table 5. Indicators of the elements of innovative activity of hotel organizations in Sochi

\begin{tabular}{|c|c|c|c|c|c|c|c|c|c|c|c|}
\hline \multicolumn{2}{|c|}{ Indicators EIA } & 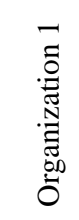 & 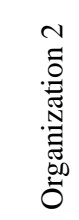 & 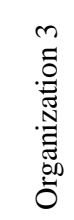 & 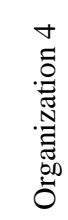 & 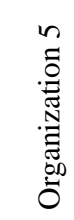 & 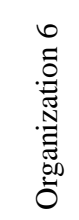 & 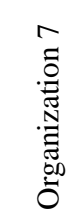 & 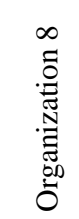 & 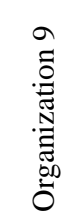 & 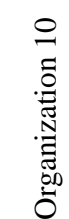 \\
\hline \multirow{8}{*}{ IP } & $\mathrm{ICp}$ & 0,09 & 0,06 & 0,09 & 0,07 & 0,20 & 0,08 & 0,07 & 0,14 & 0,06 & 0,07 \\
\hline & HEPS & 0,23 & 0,13 & 0,06 & 0,03 & 0,15 & 0,15 & 0,10 & 0,14 & 0,10 & 0,08 \\
\hline & DPS & 0,08 & 0,07 & 0,08 & 0,02 & 0,10 & 0,12 & 0,08 & 0,05 & 0,11 & 0,18 \\
\hline & TPC & 0,39 & 0,28 & 0,28 & 0,04 & 0,05 & 0,20 & 0,45 & 0,16 & 0,83 & 0,05 \\
\hline & IPRC & 0,11 & 0,07 & 0,11 & 0,11 & 0,18 & 0,23 & 0,17 & 0,14 & 0,13 & 0,06 \\
\hline & TPIC & 0,01 & 0,04 & 0,02 & 0,10 & 0,07 & 0,06 & 0,00 & 0,05 & 0,06 & 0,06 \\
\hline & CREC & 0,32 & 0,36 & 0,65 & 0,20 & 0,16 & 0,11 & 0,81 & 0,03 & 0,27 & 0,52 \\
\hline & TRFA & 0,13 & 0,07 & 0,13 & 0,18 & 0,06 & 0,08 & 0,10 & 0,09 & 0,16 & 0,31 \\
\hline \multirow{5}{*}{ IU } & AUR & 0,27 & 0,39 & 0,28 & 0,09 & 0,33 & 0,64 & 0,15 & 0,20 & 0,40 & 0,95 \\
\hline & MANR & 0,15 & 0,17 & 0,15 & 0,25 & 0,19 & 0,07 & 0,03 & 0,14 & 0,23 & 0,35 \\
\hline & HSP & 0,10 & 0,10 & 0,16 & 0,03 & 0,00 & 0,08 & 0,24 & 0,08 & 0,10 & 0,02 \\
\hline & PSR & 0,17 & 0,08 & 0,15 & 0,10 & 0,05 & 0,19 & 0,28 & 0,28 & 0,33 & 0,08 \\
\hline & IGR & 0,30 & 0,11 & 0,31 & 0,12 & 0,64 & 0,14 & 0,20 & 0,11 & 0,33 & 0,10 \\
\hline \multirow{3}{*}{ II } & IFS & 0,13 & 0,15 & 0,16 & 0,16 & 0,27 & 0,16 & 0,27 & 0,03 & 0,29 & 0,19 \\
\hline & FII & 0,27 & 0,34 & 0,37 & 0,38 & 0,75 & 0,04 & 0,41 & 0,01 & 0,07 & 0,01 \\
\hline & CHSS & 0,06 & 0,10 & 0,16 & 0,33 & 0,15 & 0,02 & 0,23 & 0,23 & 0,21 & 0,14 \\
\hline
\end{tabular}

Based on the data of table 5, by correlating the values to the maximum for the period under consideration, the normalized values of the EIA indicators of hotel organizations were calculated (Table 6).

Methodology. For a comprehensive assessment of innovation activity, we suggest using integral indicators, defined as the root of the product of all relevant indicators: 


$$
\begin{aligned}
& \Sigma(\mathrm{IP})=\sqrt[8]{\mathrm{ICp} * \mathrm{HEPS} * \mathrm{DPS} * \mathrm{TPC} * \text { IPRC } * \text { TPIC } * \text { CREC } * \text { TRFA }}, \\
& \Sigma(\mathrm{IU})=\sqrt[5]{\text { AUR } * \text { MANR } * \text { HSP } * \text { PSR } * \text { IGR }} \\
& \Sigma(\mathrm{II})=\sqrt[8]{\mathrm{IFS} * \text { FII } * \text { CHSS }}
\end{aligned}
$$

\begin{tabular}{|c|c|c|c|c|c|c|c|c|c|c|c|}
\hline \multicolumn{2}{|c|}{ Indicators } & 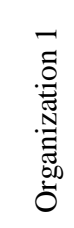 & 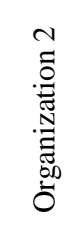 & 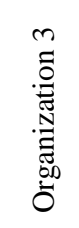 & 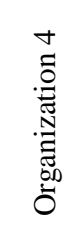 & 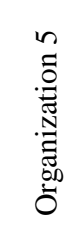 & 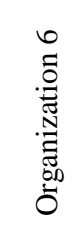 & 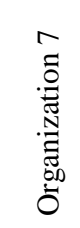 & 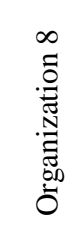 & 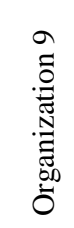 & 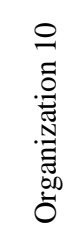 \\
\hline \multirow{8}{*}{ IP } & ICp & 0,44 & 0,31 & 0,47 & 0,35 & 1,00 & 0,42 & 0,33 & 0,72 & 0,31 & 0,36 \\
\hline & HEPS & 1,00 & 0,56 & 0,27 & 0,12 & 0,64 & 0,65 & 0,41 & 0,62 & 0,43 & 0,33 \\
\hline & DPS & 0,44 & 0,41 & 0,46 & 0,12 & 0,54 & 0,65 & 0,45 & 0,29 & 0,63 & 1,00 \\
\hline & TPC & 0,47 & 0,34 & 0,33 & 0,05 & 0,06 & 0,24 & 0,54 & 0,19 & 1,00 & 0,06 \\
\hline & IPRC & 0,47 & 0,31 & 0,45 & 0,49 & 0,76 & 1,00 & 0,71 & 0,59 & 0,55 & 0,26 \\
\hline & TPIC & 0,14 & 0,42 & 0,23 & 1,00 & 0,73 & 0,65 & 0,03 & 0,50 & 0,65 & 0,66 \\
\hline & CREC & 0,39 & 0,44 & 0,8 & 0,25 & 0,20 & 0,13 & 1,00 & 0,04 & 0,33 & 0,64 \\
\hline & TRFA & 0,43 & 0,23 & 0,44 & 0,58 & 0,19 & 0,25 & 0,32 & 0,29 & 0,51 & 1,00 \\
\hline \multicolumn{2}{|c|}{$\sum(\mathrm{IP})$} & 0,65 & 0,60 & 0,64 & 0,50 & 0,62 & 0,64 & 0,60 & 0,55 & 0,72 & 0,64 \\
\hline \multirow{5}{*}{ IU } & AUR & 0,29 & 0,41 & 0,3 & 0,09 & 0,35 & 0,68 & 0,16 & 0,21 & 0,42 & 1,00 \\
\hline & MANR & 0,44 & 0,5 & 0,43 & 0,73 & 0,55 & 0,19 & 0,09 & 0,40 & 0,66 & 1,00 \\
\hline & HSP & 0,44 & 0,42 & 0,7 & 0,11 & 0,02 & 0,32 & 1,00 & 0,32 & 0,42 & 0,09 \\
\hline & PSR & 0,52 & 0,25 & 0,46 & 0,29 & 0,14 & 0,59 & 0,84 & 0,86 & 1,00 & 0,25 \\
\hline & IGR & 0,47 & 0,17 & 0,49 & 0,19 & 1,00 & 0,22 & 0,31 & 0,17 & 0,52 & 0,15 \\
\hline \multicolumn{2}{|c|}{$\Sigma(\mathrm{IU})$} & 0,65 & 0,57 & 0,68 & 0,45 & 0,48 & 0,59 & 0,57 & 0,57 & 0,75 & 0,57 \\
\hline \multirow{3}{*}{ II } & IFS & 0,46 & 0,52 & 0,55 & 0,55 & 0,96 & 0,55 & 0,93 & 0,10 & 1,00 & 0,68 \\
\hline & FII & 0,36 & 0,45 & 0,5 & 0,51 & 1,00 & 0,06 & 0,55 & 0,02 & 0,09 & 0,01 \\
\hline & CHSS & 0,17 & 0,31 & 0,5 & 1,00 & 0,46 & 0,07 & 0,70 & 0,71 & 0,65 & 0,43 \\
\hline \multicolumn{2}{|c|}{$\Sigma(\mathrm{II})$} & 0,55 & 0,65 & 0,72 & 0,81 & 0,87 & 0,36 & 0,84 & 0,32 & 0,62 & 0,37 \\
\hline \multicolumn{2}{|c|}{$\sum(\mathrm{EIA})$} & 0,61 & 0,61 & 0,68 & 0,57 & 0,64 & 0,51 & 0,66 & 0,46 & 0,69 & 0,51 \\
\hline
\end{tabular}

Table 6. Normalized values of indicators of EIA of hotel organizations in Sochi with the calculation of integral indicators

As can be seen from Table 6, the highest value of the integral indicator of innovation activity $\square$ (NUE) is shown by Organization $9(0.69)$, the smallest - Organization $8(0.46)$.

Based on the obtained values, a petal diagram is constructed, representing the highest and lowest integral levels of innovation activity among the organizations under consideration (Figure 4). 


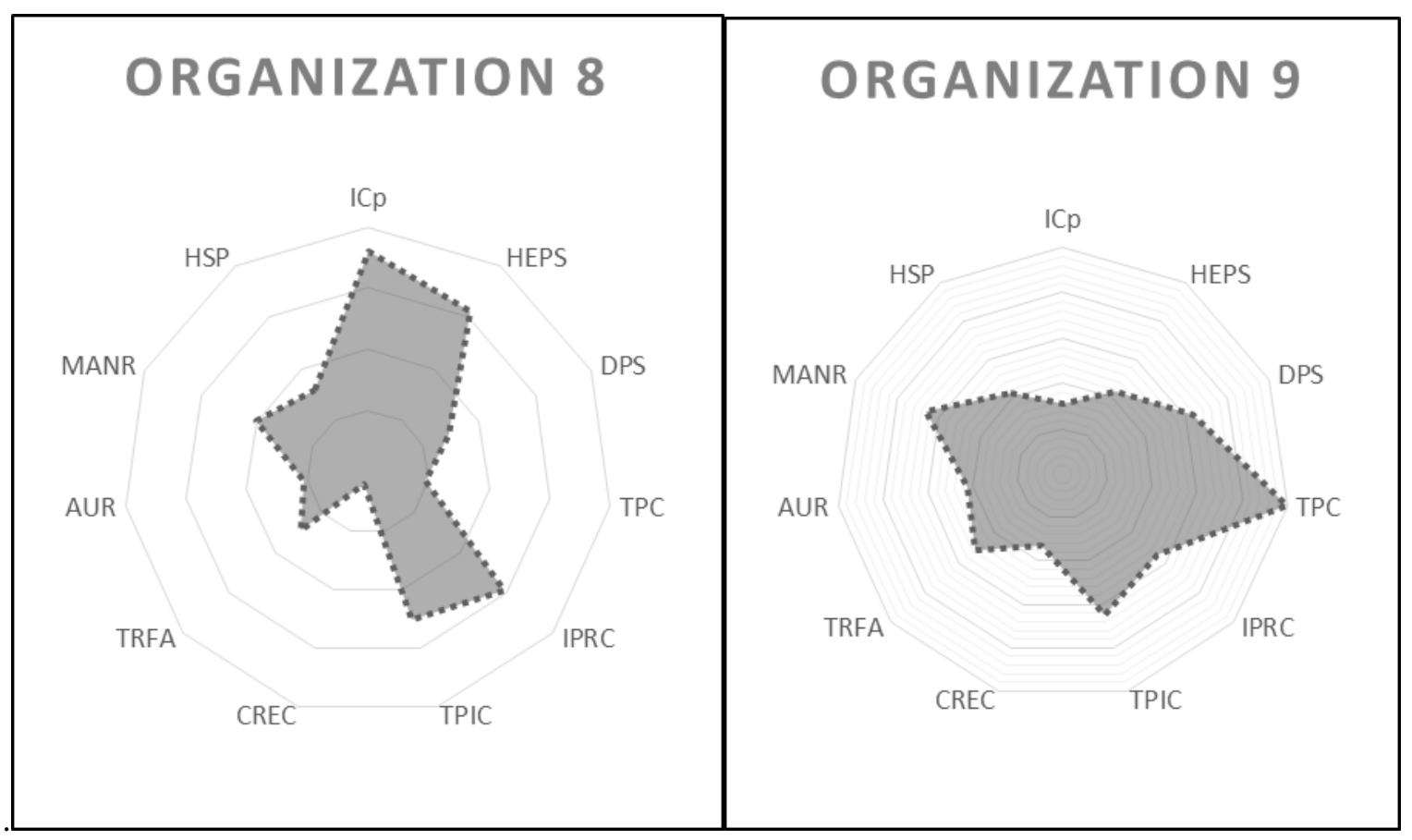

Figure 4. Comparison of the smallest and highest level of the integral indicator of innovative activity of hotel organizations in Sochi

According for the previous research, the main role for the After plotting the dependence $\operatorname{lnK}=\mathrm{f}(\mathrm{t})$, it was hypothesized that the dependence can be represented in the form of a regression equation of the form: $y=a+b x$. The adequacy of the model was estimated by the value of the Fisher criterion. Therefore, the developed model is adequate, the program works correctly.

After calculating the reaction rate constants, the dependence $K=\mathrm{f}(\mathrm{t})$ was constructed. When visual assessment of the graphs are observed depending on the experimental and calculated values.

\section{Conclussion}

Summing up the research, we can conclude that the proposed approach to the assessment of innovative activity, based on integral indicators and stochastic factor modeling of the resulting effects, allows to determine key factors and indicators, the development of which will most contribute to the sustainable innovative development of hotel organizations (Krajukhin et al. 2012).

Using this methodological approach allows you to determine the current efficiency of ongoing innovation processes and the prospects of their further development and implementation, to determine the factors of positive and negative impact on the organization's innovation activities, as well as to diagnose the weak points of existing elements of innovation activity in order to optimally manage them.

Of practical interest is a comparison of the integral indicator with similar indicators of the company's main competitors, leaders of innovation development, as well as with an indicator calculated on the basis of statistical data of enterprises of the hospitality industry (Reutov, Prakticheskaja 2015). 


\section{ENTREPRENEURSHIP AND SUSTAINABILITY ISSUES}

ISSN 2345-0282 (online) http://jssidoi.org/jesi/

2019 Volume 6 Number 4 (June)

http://doi.org/10.9770/jesi.2019.6.4(43)

\section{References:}

Abdukarimov I. T. (2013) Faktory, vlijajushhie na rezul'tativnye pokazateli hozjajstvennoj dejatel'nosti predprijatij, ih klassifikacija i metody ocenki [Factos impacting resulting indictors of entreprise activity, their classification and methods of evaluation]. Social'nojekonomicheskie javlenija i processy. Tambov 12: 9-14.

Abdukarimov I. T., Narizhnyj I. F. (2014) Faktornyj analiz ocenki vlijanija faktorov vnutrennej sredy predprijatija na rezul'tativnye pokazateli ego hozjajstvennoj dejatel'nosti, [Factor analysis of the assessment of the influence of factors of the internal environment of the enterprise on the performance indicators of its economic activity] Region: sistemy, jekonomika, upravlenie 3(26): $123-131$.

Akaka, M. A., \& Vargo, S. L. (2014). Technology as an operant resource in service (eco) systems. Information Systems and e-Business Management 12(3): 367-384.

Alvesson, M., \& Karreman, D. (2000). Varieties of discourse: On the study of organizations through discourse analysis, Human Relations 53(9): 1125-1149.

Anisimov Ju.P., Peshkova Ju.V., Solnceva E.V. (2006). Metodika ocenki innovacionnoj dejatel'nosti predprijatija, [Methodology for assessing the innovation activity of an enterprise.] Innovacii 11: 88-90.

Battour, M., \& Ismail, M. N. (2016). Halal tourism: Concepts, practices, challenges and future, Tourism management perspectives 19: 150154.

Beketov N.V. (2008). Innovacionnaja dejatel'nost' i innovacionnyj process: sushhnost' i osnovnye jetapy issledovanija v jekonomicheskoj literature [Innovation activity and the innovation process: the essence and the main stages of research in the economic literature,] Ekonomicheskij analiz: teorija i praktika 3: 11-16.

Bovin, A. A. (2011). Upravlenie innovacijami v organizacii: ucheb. Posobie [Innovation management in the organization: studies. book] /A. A. Bovin, L. E. Cherednikova, V. A. Jakimovich. - M.: Omega-L. 416p.

Buhalis, D., \& Law, R. (2008). Progress in tourism management: 20 years on and 10 years after the internet - the state of e-Tourism research, Tourism Management 29(4): 609-623. https://doi.org/10.1016/j.tourman.2008.01.005

Chkalova, O., Efremova, M., Lezhnin, V., Polukhina, A., Sheresheva, M. (2019). Innovative mechanism for local tourism system management: a case study, Entrepreneurship and Sustainability Issues 6(4): 2052-2067. http://doi.org/10.9770/jesi.2019.6.4(35)

Dezhkina, I. P. (2012). Innovacionnyj potencial hozjajstvennoj sistemy i ego ocenka (metody formirovanija i ocenki) [Innovative potential of the economic system and its assessment (methods of formation and assessment)] / I. P. Dezhkina. - M.: Infra-M, 122 p.

Fathutdinov, R. A. (2013). Innovacionnyj menedzhment: uchebnik dlja vuzov [Innovation Management: a textbook for universities] / R. A. Fathutdinov. - SPb: Piter, 448 p.

Galkina, A. N. (2011). Kriterii ocenki jeffektivnosti innovacionnyh processov v organizacii [Criteria for evaluating the effectiveness of innovation processes in organizations], Ekonomicheskij analiz: teorija i praktika 43 (250): 10-23.

Indikatory innovacionnoj dejatel'nosti. [Innovation Indicators] (2012). stat. sb. M.: Nacional'nyj issledovatel'skij universitet «Vysshaja shkola jekonomiki», 472p.

Kokurin, D. I. (2011). Innovacionnaja dejatel'nost' [Innovative activity]/ D. I. Kokurin. - M.: Jekzamen, 576p.

Krajuhin G.A., Ershov V.F., Frajmovich V.B. (2012). Upravlenie innovacionnym razvitiem predprijatij i organizacij na osnove izmenenij, [Management of innovative development of enterprises and organizations based on changes] Vestnik INZhJeKONa 1: 144-148.

Kuznecova T.E., Rud' V.A. (2013.) Konkurencija, innovacii i strategija razvitija rossijskih predprijatij [Competition, innovation and development strategy of Russian enterprises] (rezul'taty jempiricheskih issledovanij), Voprosy jekonomiki. 12: 86-108. 


\section{ENTREPRENEURSHIP AND SUSTAINABILITY ISSUES}

ISSN 2345-0282 (online) http://jssidoi.org/jesi/

2019 Volume 6 Number 4 (June)

http://doi.org/10.9770/jesi.2019.6.4(43)

Malysheva L.A., Shestakov I.V. (2012). Analiz podhodov k ocenke innovacionnoj aktivnosti rossijskih predprijatij [Analysis of approaches to the assessment of innovative activity of Russian enterprises] http://www.sr.pstu.ru/files/VestnikSocialnojekonnomnauki14_2012.pdf

Mariev O.S., Savin I.V. (2010). Faktory innovacionnoj aktivnosti rossijskih regionov: modelirovanie i jempiricheskij analiz. [Factors of innovation activity of the Russian regions: modeling and empirical analysis] Ekonomika regiona 3: 235-244.

Medlik, S. (2012). Dictionary of travel, tourism and hospitality. Routledge, 679p.

Mohsin, A., Ramli, N., \& Alkhulayfi, B. A. (2016). Halal tourism: Emerging opportunities, Tourism Management Perspectives 19: 137143.

Munar, A. M. (2012). Social media strategies and destination management, Scandinavian Journal of Hospitality and Tourism 12(2): 101120. https://doi.org/10.1080/15022250.2012.679047

Nikolova, M. S., \& Hassan, S. S. (2013). Nation branding effects on retrospective global evaluation of past travel experiences, Journal of Business Research 66(6); 752-758.

Osnovy innovacionnogo menedzhmenta. [Fundamentals of innovation management] Teorija i praktikapod red. P. N. Zavlina, A. K. Kazanceva, L. Je. Mindeli. - M.: Ekonomika, 2004. - 518 s.

Panfiluk, E.; Szymańska, E. (2017). The measurement of the innovativeness of health tourism services using an adequacy matrix, Entrepreneurship and Sustainability Issues 4(4): 400-420. http://doi.org/10.9770/jesi.2017.4.4(1)

Petrenko, Y., Vechkinzova, E., Antonov, V. (2019). Transition from the industrial clusters to the smart specialization of the regions in Kazakhstan, Insights into Regional Development 1(2): 118-128. https://doi.org/10.9770/ird.2019.1.2(3)

Pröbstl-Haider, U., Melzer, V., \& Jiricka, A. (2014). Rural tourism opportunities: strategies and requirements for destination leadership in peripheral areas, Tourism Review 69(3): 216-228.

Reutov A.Ju. Prakticheskaja 2015. Interpretacija kolichestvennoj ocenki innovacionnoj aktivnosti organizacii [Interpretation of the quantitative assessment of innovative activity of the organization] http://rus.neicon.ru:8080/xmlui/bitstream/handle/123456789/2627/12_352-160.pdf?sequence=1

Rumjanceva A.V., Egorova I.S. 2015. Pokazatelej dlja ocenki jeffektivnosti funkcionirovanija sub\#ektov innovacionnoj sistemy Rossii. [Indicators to assess the performance of the subjects of the innovation system of Russia] URL:http://vestnik.urfu.ru/archive/statja/Journal/article/44/sistema-pokazatelei-dlja-ocenki-ehffektivnosti-funkcio/

Ryan, C., \& Page, S. (Eds.). (2012). Tourism Management. Routledge, 347p.

Sheremet A. D. (2011). Teorija ekonomicheskogo analiza. [Theory of Economic Analysis] M.: INFRA-M, 352p.

Shevyakova, A., Munsh, E., Arystan, M. (2019). Information support for the development of tourism for the diversification of the economy of Kazakhstan, Insights into Regional Development 1(2): 138-154. https://doi.org/10.9770/ird.2019.1.2(5)

Tarlow, P. (2007). Dark tourism-the appealing 'dark'side of tourism and more. In Niche tourism (pp. 61-72). Routledge, 345p.

Vertakova Ju.V., Vaganova O.V. 2012. Vydelenie prioritetov innovacionnogo razvitija regiona na osnove integral'noj ocenki, [Highlighting the priorities of innovative development of the region based on an integrated assessment] Region: sistemy, jekonomika, upravlenie 1: 8589

Ziyadin S., Litvishko O., Dubrova M., Smagulova G., Suyunchaliyeva M. (2019) Diversification tourism in the conditions of the digitalization, International Journal of Civil Engineering and Technology (IJCIET) 10(2): 1055-1070 http://www.iaeme.com/ijciet/issues.asp?JType=IJCIET\&VType=10\&IType $=02$

Ziyadin, S., Kabasheva, N. (2018). The Basis for Initiating the Eurasian Integration of the Agricultural Sector, Public Administration Issues. Special Issue (electronic edition), pp. 56-67 


\section{ENTREPRENEURSHIP AND SUSTAINABILITY ISSUES}

ISSN 2345-0282 (online) http://jssidoi.org/jesi/

2019 Volume 6 Number 4 (June)

http://doi.org/10.9770/jesi.2019.6.4(43)

Sayabek ZIYADIN is the Professor, Doctor of economic science and Director of the Center for Economic Research at al-Farabi Kazakh National University. His work has attracted best research paper awards in both the database Scopus and the Clarivate. Research interests: tourism and regional development; innovation and digitalization; project management; sustainability.

ORCID ID: orcid.org/0000-0001-7219-1545

Nataliya SHASH is the Professor, Doctor of economic science at Plekhanov Russian University of Economics. Research interests: finance and regional development; innovation and digitalization; project management; sustainability

ORCHID ID: orcid.org/0000-0003-2779-6961

Tatyana LEVCHENKO is Professor of the Department of hotel and restaurant business at Sochi State University. Research interests: tourism and innovation management in the hospitality industry, innovations in sanatorium and resort activities, features of economic analysis in the hospitality industry.

ORCHID ID orcid.org/0000-0003-0161-7582

Saltanat KHUDAIBERGENOVA is doctoral student at at al-Farabi Kazakh National University. Research interests: regional development; innovation and marketing; project management; tourism.

ORCHID ID: orcid.org/0000-0003-4895-5298

Gulmira YESSENOVA is associate professor at Seifullin Kazakh AgroTechnical University. Research interests: finance; innovation and marketing; education management; tourism.

ORCHID ID: orcid.org/0000-0002-4576-3920 
ENTREPRENEURSHIP AND SUSTAINABILITY ISSUES

ISSN 2345-0282 (online) http://jssidoi.org/jesi/

2019 Volume 6 Number 4 (June)

http://doi.org/10.9770/jesi.2019.6.4(43)

Register for an ORCID ID:

https://orcid.org/register

Copyright (C) 2019 by author(s) and VsI Entrepreneurship and Sustainability Center

This work is licensed under the Creative Commons Attribution International License (CC BY).

http://creativecommons.org/licenses/by/4.0/

(c) (7) Open Access 